\title{
UNIVERSITYOF
}

FORWARD

THINKING

WESTMINSTER用

WestminsterResearch

http://www.westminster.ac.uk/westminsterresearch

Communism in Cold War Belfast, 1945-62

Smylie, $\mathbf{P}$.

This is an accepted manuscript of an article published by Liverpool University Press in Labour History Review, 85 (1), pp. 59--83.

The final definitive version is available online:

https://dx.doi.org/10.3828//hr.2020.3

(C) 2020 Liverpool University Press

The WestminsterResearch online digital archive at the University of Westminster aims to make the research output of the University available to a wider audience. Copyright and Moral Rights remain with the authors and/or copyright owners. 


\section{Communism in Cold War Belfast, 1945-62}

\section{Introduction}

By 1945, the first generation of Belfast communists, schooled in the tumultuous thirties, were surely sanguine about their party's future. Communist Party (CP) membership had mushroomed from approximately 50 in 1939 to around 1,000 in 1943, and remained close to this highpoint until the war's end. ${ }^{1}$ Indeed, the $\mathrm{CP}$ had a membership equivalent to the Northern Ireland Labour Party (NILP). ${ }^{2}$ Communist activists may also have relished the party's selfproclaimed mission, to challenge a Stormont Government, which they believed had 'No Plan for [post-war] Transition'. ${ }^{3}$ Wartime growth in trade union membership further fuelled optimism. CP activism in the wider labour movement was such that, in 1943, the party almost succeeded in affiliating to the NILP. ${ }^{4}$ More generally, the UK electorate's support for 'socialistic' state intervention and welfare provision indicated leftward turn in British politics, while the communists themselves reaped the 'Stalin Levy', or the high public regard for the Red Army and its Generalissimo. Nevertheless, the immediate post-war period witnessed a rapid decline in $\mathrm{CP}$ membership, and whilst cadres retained significant influence in Belfast labour politics, the party singularly failed to become the focal point of opposition to the Unionist government.

Some scholars have posited the CP's reformist approach to explain its decline. Milotte points to an 'opportunist' policy, which, by subordinating rank-and-file activism and the national question in favour of co-option into the trade union bureaucracy,

\footnotetext{
${ }^{1}$ Unity, May 1945.

2 NILP membership at the time is estimated at ' 1500 at most, with around 1000 the more likely figure'. Terry Cradden, Trade Unionism, Socialism and Partition: The Labour Movement in Northern Ireland 1939-1953 (Belfast), p. 38. However, there were 17 trade unions affiliated to the NILP by the war's end whereas the CP had none.

${ }^{3}$ Unity, 18 Jan. 1945.

${ }^{4}$ Unity, 14 Aug., 16 Oct. 1943. At the decisive NILP conference the affiliation resolution was defeated by the card vote of large unions, many of whose members probably supported the $\mathrm{CP}$ effort.
} 
failed to realise the radical potential of the Protestant working class. ${ }^{5}$ Similarly, Treacy argues that, following the war, Belfast communists actually 'contributed to a narrowing of politics which saw a solidification of Protestant working class support for reactionary [Ulster] Unionism'. ${ }^{6}$ Both works are highly critical of northern communism. Milotte's pioneering study, which relied on a relatively narrow source base, essentially represented a 'monodimensial' Trotskyist critique. ${ }^{7}$ While Treacy's study utilises novel sources it lacks a sustained interpretative framework. For instance, the indeterminate, and largely accusatory, phrase 'Stalinism' is consistently employed to explain thinking, while there are significant issues concerning inadequate referencing and the frequently conspiratorial tone. Elsewhere, Byers's nuanced biography of Seán Murray, a 'republican communist' and the 'brains' of the $\mathrm{CP}$, primarily views post-war events in terms of prevailing Irish conditions rather than Soviet foreign policy. Nevertheless, Byers's argument that, during late 1950s, 'Belfast communists remained on the margins of politics and had yet to define clearly who or what they represented' understates the domestic Cold War and its impact on the CP's own identity and positioning vis-á-vis the Irish national question. ${ }^{8}$

This article provides a more comprehensive study encompassing the three fundamentals of analysis of any communist party in this period: its internal workings, organisation, policies, and rank-and-file activism; the impact of the Cold War; and finally the broader context within its host society. ${ }^{9}$ It commences in the immediate post-war years, discussing rapid membership decline and the deteriorating relationship with the NILP. It then analyses growing anti-communist sentiment apparent in the late 1940s as the Cold War

\footnotetext{
${ }^{5}$ Mike Milotte, Communism in Modern Ireland: The pursuit of the Workers' Republic since 1916 (Dublin, 1984) p. 262.

${ }^{6}$ Matt Treacy, The Communist Party of Ireland 1921-1969 (Dublin, 2012) p. 198.

${ }^{7}$ Kevin Morgan, Against Fascism and War: Ruptures and Continuities in British Communist Politics, 1935-41 (Manchester, 1989), p. 6.

${ }^{8}$ Seán Byers, Seán Murray: Marxist-Leninist and Irish Socialist Republican (Dublin, 2015), p. 179.

9 Perry Anderson, 'Communist Party history', in Raphael Samuel (ed), People's History and Socialist Theory, (London, 1981), pp. 145-56.
} 
intensified, while domestically both Irish governments adopted increasingly trenchant positions on partition. The third section deals with the ensuing domestic Cold War, outlining how the communist presence in the trade unions was the overriding concern of the party and of the anti-communist forces ranged against it. Following this, the article discusses the CP's approach to the national question. The conclusion argues the party's primary orientation lay in the sphere of Belfast labour politics, and that its opposition to partition as much as its commitment to Marxism-Leninism marked it out from its main rival, the NILP.

\section{From Wartime Honeymoon to Post-War Divorce}

In May 1945 CP General Secretary William McCullough confidently stated 'twenty five per cent of the party membership was drawn from the middle classes and included a large number of professional men and women' ${ }^{10}$ A religious breakdown of the membership does not exist but the majority would have been Protestant industrial workers. ${ }^{11}$ The appeal would have been involvement in a party fully committed to the 'the people's war'. ${ }^{12}$ Throughout 1943-45, Unity was replete with advertisements for 'socials, political meetings and combinations of the two. For example, members could join a 'Workers' Theatre Group' production, 'Hands off Greece' ${ }^{13}$ Made relatively popular by their wartime commitment and having tempered their revolutionary aspirations, communists believed they could have a voice in a post-war 'Progressive Coalition'.${ }^{14}$ A delegate to the 1945 party congress provided the rationale for this

\footnotetext{
${ }^{10}$ Irish Times, 31 May 1945.

${ }^{11}$ Marilyn Hyndman, Further Afield: Journeys from a Protestant past (Dublin, 1996), p. 68.

${ }^{12}$ Controversially this entailed maintaining a policy 'of opposing all strikes which threatened war production' even when, in February 1944, a strike at Harland and Wolff shipyard involving 3,000 workers led to the jailing of five shop stewards and precipitated tens of thousands workers being called out by Belfast's shop stewards' movement . Cradden, Trade Unionism, pp. 27-28.

${ }^{13}$ Unity, 15 Feb. 1945.

${ }^{14}$ Loughlin has noted that the CP's 'Progressive Coalition' can be traced back to the 'Popular Front' politics of the 1930s. Christopher Loughlin, 'The Long Civil Rights Movement in Northern Ireland: Labour and Progress in Loyal Ulster, 1921-1939’(eds), Seán Byers \& Francis Devine, William Walker 1870-1918, Belfast Labour Unionist Centenary Essays, (Dublin, 2018), p. 87.
} 
reformist turn in revolutionary terms: 'In order to build a mass party we would have to come away from the former narrow revolutionary outlook and acquire a broadened revolutionary outlook so that the Party could comprise all sections of the people'. ${ }^{15}$ Communist parties dominating or sharing power in 'Popular Front' governments throughout Europe provided the broader context to the sentiment evident here. In Belfast, a tacit pact between the NILP and the CP ensured they would not run candidates against each other during the 1945 Stormont election. ${ }^{16}$

The left in Northern Ireland, however, did not replicate Labour's breakthrough in Britain. Indeed, whilst parties and candidates broadly of the left gained in the region of 126,000 votes, against approximately 196,000 for Unionists, and the election marked the peak of popular support for the party, the outcome disappointed members. ${ }^{17}$ Malachy Gray recalled the 'overwhelming bitterness in the whole Labour Movement at the return of a Unionist government despite the tremendous activity of the war years' ${ }^{18}$ Andy Barr remembered the financial cost of the 'massive campaign' which 'had the Party bankrupt' ${ }^{19}$ The CP's candidates had polled well. In Belfast, McCullough got 5,802 votes in the Bloomfield division, whilst Betty Sinclair polled 4,130 in Cromac. Perhaps the most impressive poll for the CP occurred in largely rural West Down, where Sid Maitland, 'a young electrician' working from a base in Banbridge, received 2,524 votes despite suffering physical attacks by Unionists during the campaign. ${ }^{20}$

\footnotetext{
${ }^{15}$ Unity, 8 Mar. 1945.

${ }^{16}$ Cradden, Trade Unionism, p. 44.

${ }^{17}$ Cradden, Trade Unionism, p. 45.

${ }^{18}$ Malachy Gray, 'A Shop Steward Remembers', in Saothar: Journal of the Irish Labour History, 11 (1986), p. 114.

${ }^{19}$ Francis Devine, 'An Undiminished Dream: Andy Barr, Communist Trade Unionist', in Saothar: Journal of the Irish Labour History, 16 (1990), p. 101.

${ }^{20}$ Newry Reporter, 12 Jun. 1945.
} 
One effect of the 'labourist upsurge' at the polls was that it helped convince the Ulster Unionist Prime Minister, Sir Basil Brooke, that 'the government had to embrace the welfare state no matter how much this enraged many party members' ${ }^{21}$ Moreover, Unionist alarm at the ongoing challenge posed by the left continued into 1946. In June, Brooke recommended the setting up of 'an organisation to fight Communism and Socialism, namely by creating cells throughout the various factories and industries', and, in July, he stated that a newly formed Publicity and Propaganda Sub-Committee should 'provide Unionist supporters with answers to Socialist and Communist arguments, by issue of leaflets, and if the demand warrants it, the formation of study classes'.22

Unfortunately for the CP, its accommodation with the NILP did not last. The local government elections of September 1946 ended in recrimination as a split left vote between two communist and four labour candidates allowed Unionists to take all four seats in the Pottinger ward. ${ }^{23}$ More worryingly, the 'pioneering work' done on behalf of Maitland during the Stormont election led to the election of four NILP councillors but no communists. ${ }^{24}$ Prior to this, in May 1946, Unity published correspondence detailing the CP's second attempt at affiliation to the NILP and its curt rejection. ${ }^{25}$

By that point, the CP's difficulties were increasingly apparent. Within weeks of the affiliation letter's publication, the Irish Times was able to report: 'Communism, one of the outstanding features of Northern Ireland's political life during the war, has been declining somewhat since the end of the hostilities' ${ }^{26}$ Falling donations made to the Unity fund meant

\footnotetext{
${ }^{21}$ Henry Patterson, 'The Decline of the Collaborators', in F. Devine, F. Lane, and N. Puirséil (eds), Essays in Labour History: A Festschrift for Elizabeth and John W. Boyle (Dublin, 2008), p. 241.

22 'UUC advisory body', 19 Jun. 1946, 26 Jul. 1946, Belfast, Public Record Office of Northern Ireland (P.R.O.N.I.), Ulster Unionist Council papers, (D/1327/15/9).

${ }^{23}$ Unity, 12 Oct. 1946.

${ }^{24}$ Review, Nov. 1946.

25 Unity, 4 May 1946.

${ }^{26}$ Irish Times, 29 May 1946.
} 
the journal had to change from a weekly to a monthly in September before collapsing altogether early in 1947. The party could not raise the $£ 30$ a month needed to keep it going. Old attitudes towards communism were resurfacing in the press and amongst Belfast's trade union leaders:

As one surveys the British industrial scene one is apprehensive that the trade union movement may come under the complete control of persons of Communist, revolutionary or totalitarian tendencies; it matters not which name is used; all mean the same thing in practice. Are we to see in these islands a repetition of the conflicts between the Communist controlled unions and craft unions which for years have upset industrial life in the U.S.A.? And will Northern Ireland be exempt from the effects of such control? To those who give any thought to such matters, what happened to the trade unions in Italy and Germany should provide food for thought. Nor can the position in Russia be ignored; there the trade unions are mere puppets on the state stage, and the members chattels of the State. ${ }^{27}$

The brief post-war honeymoon was over and party membership underwent a 'significant retraction' ${ }^{28}$

Organisational deficiencies and missteps did not help matters. 'Democratic centralism' gave the party leadership control over policy and made the incumbent Executive Committee difficult to challenge and, in public at least, the 'party's voice was always a single and united one' ${ }^{29}$ On the other hand, work, authority, and perhaps most importantly a sense of responsibility remained in the hands of a small coterie of leading individuals. Morrissey suggests that by the war's end 'while the leadership had gained great influence inside the labour movement, the ordinary members had felt neglected and uninvolved' ${ }^{30}$ Members 'losing contact' affected party finances and the party's full time industrial organiser, Michael McInerney, proposed 'an organisation of dues collectors to visit the homes of members and keep them acquainted with policy' ${ }^{31}$ This thinking, mirroring developments in the CPGB, led to an organisational shift from workplace 'groups' to residential branches 'as the basic unit of

\footnotetext{
${ }^{27}$ The Gazette, October 1946. This was the journal of the Northern Ireland Post Office Clerks' Association. The background to this statement by E. Fails, General Secretary of this semi-official union was a claim by the Union of Post Office Workers for the sole right to negotiate on behalf of rank-and-file grades in the post-office. As such, it probably represented an opportunist use of anti-communism that pre-dated the Cold War proper.

${ }^{28}$ Hazel Morrissey, 'Betty Sinclair: A Woman's Fight for Freedom', in Saothar: Journal of the Irish Labour History Society, 9 (1983), p. 127.

${ }^{29}$ Terry Cradden, 'The Left in Northern Ireland and the National Question: The 'Democratic Alternative' in the 1940s' Saothar: Journal of the Irish Labour History Society, 16 (1991), p. 39.

${ }^{30}$ Morrissey, 'Betty Sinclair', p. 127.

${ }^{31}$ Ibid.
} 
the Party'. ${ }^{32}$ However, the CP's subsequent decline suggests the restructuring represented a costly mistake made of desperation. British intelligence documents reveal that:

since the result of the elections last year public support, financially and otherwise for the Party here has decreased and for some time past there has been friction amongst the leading members of the Party. The matter of retrenchment has been discussed... it was generally accepted by the Executive that the services of one or two of the paid officers, there are usually four or five in the Party, would have to be dispensed with...This did not suit McInerney who has no other occupation and so far as we can gather wants to secure McCullough's position as General Secretary. ${ }^{33}$

The primacy of workplace organisation, which had never totally disappeared, became paramount once again as the Cold War developed. ${ }^{34}$

In May 1948, the Organisation Committee had 'a target of 200 membership... by the end of June' and it aimed at getting 'the shipyard and aircraft [factory] groups going again.'35 The party issued 30 membership cards to shipyard workers in 1949, but fell short of recruiting a 200 membership, with 172 cards issued. Moreover, the CP had only two strong branches in Belfast, 'North' and 'East', with 60 members apiece. ${ }^{36}$ Outside Belfast, the party struggled to establish itself. During the war, communist members of the Amalgamated Engineering Union led an active party branch in Banbridge, but this faded out of existence in the post-war period. ${ }^{37}$ In Coleraine, which had a strong leftist tradition dating from the 1930s, a 'group' successfully carried out a wartime policy of entryism into the local NILP branch. One communist, E.A. McLaughlin, was branch secretary, election agent and sat as an NILP representative on the borough council, but the 'movement' in Coleraine 'disintegrated' between 1946 and $1950 .{ }^{38}$ In 1950, a CP 'group' was successfully set up Derry city, whilst 'contacts' were established in

\footnotetext{
${ }^{32}$ For CPGB see John McIlroy, 'Reds at Work: Communist Factory Organisation in the Cold War, 1947-56', in Labour History Review, Vol. 65, no. 2 (2000), pp.181-201; Unity, 15 Feb. 1945.

33 'Extract from letter from Royal Ulster Constabulary', 21 Mar. 1946, London, National Archives, MI5 file on Betty Sinclair, (KV2/2506).

34 'Communist Party Conference,' 4-5 Feb. 1950 (P.R.O.N.I., Sean Murray papers (SMP), D/2162/G/13).

35 'Organisation and Finance Committee minutes', 1948-49 (P.R.O.N.I., SMP, D/2162/G/9).

${ }^{36}$ Ibid.

${ }^{37}$ Banbridge Chronicle, 17, 24 Feb., 21 Apr., 5 May, 2 Jun. 1945.

${ }^{38}$ CPGB Personnel Files, E. A. McLaughlin, n.d. c.1951, Manchester, Labour History Archive and Study Centre, Communist Party of Great Britain Papers, (L.H.A.S.C.) (CP/CENT/PERS/4/07).
} 
Newry, Enniskillen and Coalisland. ${ }^{39}$ Clearly, the potential to create a mass party from the 1,000 strong wartime membership had passed.

In a sense, Belfast communists were victims of their own success as the rapid growth in membership during the war years exceeded their ability to integrate new recruits meaningfully. It is doubtful, however, that any system of organisation could have coped with the difficulties outlined above and conceivably the centralized organisation of the $\mathrm{CP}$, built around a core of dedicated activists, ensured the CP's long-term survival, albeit in a much truncated form.

\section{External Relations: the CP and the onset of the Cold War}

The party's primary concern in the immediate post-war years was the demand for increased industrial production and the nationalisation of industry, which would help facilitate it. This would create full employment and compliment resistance to 'dollar imperialism' ${ }^{40}$ The latter aspect became increasingly obsolete as Britain's economic weakness made it dependant on American credit. Nevertheless, this thinking meant Belfast communists could maintain a constructively critical, as opposed to openly hostile, stance towards the NILP and the Labour government in Britain. This was necessary because the CP, following the CPGB's example, was committed to fostering good relations between Britain, Western Europe and the Soviet Union to lessen the likelihood of a US-Soviet conflagration: 'Only unity with the Soviet Union, France and the peace-loving democratic nations of Europe and the world can guarantee peace' ${ }^{41}$ However, this meant communists had to be equivocal about the NILP, which enjoyed greater working class support, even as they were increasingly ostracised: 'It must be evident

\footnotetext{
39 'Communist Party Conference,' 4-5 Feb. 1950 (P.R.O.N.I., SMP, D/2162/G/13).

40 Unity, 14 Dec. 1946.

41 Ibid.
} 
that there is no place in this country for the existence of a political party with its policy and outlook coloured and dominated by the needs of the foreign policy of another country'. ${ }^{42}$

Had the party's response to the emerging Cold War been merely to act as an advocate for the Soviet Union, it probably would not have survived for long. Instead, it sought to maintain its position in the trade union movement, attacking the Unionist government on issues such as housing and employment whilst evading the potential pitfall of the national question. Byers has noted how 'the transition from a wartime to peacetime economy did breed resistance against attacks on jobs, wages and conditions' and created the conditions for shop stewards, including communists, to become union officials or executive members. ${ }^{43}$ Despite dwindling membership figures the party felt it more than held its own against social democrats in the unions: 'Our forces in the Shipyard and Aircraft [factory] are not numerically on a par with the undoubted influence which the Party Leadership wields in these industries' ${ }^{44}$ Communist and NILP members shared the same broad socialist ideals of public ownership and social equality reflected in the emerging welfare state, which, met with hostility by senior figures in the Unionist government, who, for instance, opposed the creation of the National Health Service. ${ }^{45}$ Both parties opposed the Stormont government's working class subsidiary, the Ulster Unionist Labour Association (UULA), which railed against perceived threats to Unionist hegemony. In 1948, for instance, the UULA's annual report stated:

The recently formed Electrical Trades Unionist Group, under its active Chairman, Mr. W. Martin, continues to grow in numbers. It is our earnest desire that sufficient members will be enrolled and that Romanist, Socialist and Communist influences, within the Branches of the Electrical Trades Union, will be effectively counteracted. ${ }^{46}$

\footnotetext{
42 'Chairman's Address to $23^{\text {rd }}$ annual conference of the NILP', 26-27 Oct. 1946, P.R.O.N.I., Belfast and District Trades Council Papers (BTC), (D/1050/17/125).

${ }^{43}$ Byers, Murray, p. 150.

44 'Communist Party Conference,' 4-5 Feb. 1950 (P.R.O.N.I., SMP, D/2162/G/13).

${ }^{45}$ Byers, Murray, p. 153.

${ }^{46}$ Patterson, 'The Collaborators', p. 244.
} 
Such attacks did not prevent the NILP, or at least sections within it, from campaigning, in similar fashion to the $\mathrm{CP}$, against repressive government measures and sectarian bodies, notably the Special Powers Act, and the B Specials. ${ }^{47}$ However, the re-emergence of the national question and the escalating Cold War, in both its international and domestic contexts, would deepen fissures with the NILP.

In February 1948, after sixteen years of uninterrupted Fianna Fáil government under Éamon De Valera, a Fine Gael dominated coalition ascended to office in Dublin. Following the election, however, de Valera embarked on an international publicity tour aimed at reprioritising the national question ostensibly in support of a broader Anti-Partition League campaign. ${ }^{48}$ In response, the coalition government asserted its own nationalist credentials, declaring a Republic and repealing Éire's link with the British Commonwealth. This cynical manipulation of the national question in southern politics made the greatest impact north of the border, but not on the Unionist government. Rather, it shattered the 'broad church' ethos of the NILP. Those who favoured the Union wanted the party to become a regional affiliate of British Labour. A sentiment at odds with the anti-partitionist constituency, which left or faced expulsion. In November 1948, the NILP effectively transformed into a pro-Union labour party, whilst the expelled anti-partitionist element combined with the Socialist Republican Party, and formed northern branches of the '32 county', or all-Ireland, Irish Labour Party. ${ }^{49}$ The NILP's subsequent declaration in favour of the existing constitutional position could not prevent its heavy defeat to a reinvigorated Unionist Party at the Stormont election, called opportunistically by Brooke, in February 1949.

\footnotetext{
${ }^{47}$ Cradden, Trade Unionism, p.144.

${ }^{48}$ Established in 1945, the Anti-Partition League organised in Ireland and in centres of Irish emigration across the world to publicise the evils of partition. In Britain, it adopted a stridently anti-communist position. See Patrick Smylie, 'The CPGB, the Connolly Association and Irish communism, 1945-1962', Labor History, 58 (2017) 639-655.

${ }^{49}$ Niamh Puirséil, The Irish Labour Party1922-73 (Dublin, 2007), pp. 137-38.
} 
The CP also felt the effect of these events. Milotte argues that this election, where Billy McCullough, standing in Belfast's Bloomfield division, was the only communist candidate, confirmed the party's 'refusal to confront partition'. ${ }^{50}$ The CP's 'Facts for speakers and canvassers', demonstrates social and industrial issues were prioritized, an undoubted weakness in 'Brooke's plebiscite'. ${ }^{51}$ If pushed on the constitutional issue, the response was to recognise the status quo: 'Northern Ireland to rid itself of the Tories go Socialist and get closer to Socialist Britain and the working people of the rest of Ireland'. ${ }^{52}$ This evidently failed to convince the electors. McCullough finished third behind the Unionist and NILP candidates, his vote plummeting from 5,802 in 1945 to 623 . Prevailing northern political realities militated against the $\mathrm{CP}$ adopting a resolute anti-partitionist position. The election result meant republicans, notably Murray, had to acknowledge the party's electoral constituency and membership came from predominantly Unionist areas of Belfast. Furthermore, the presence of a labour candidate, where McCullough had previously enjoyed a straight contest with Unionism, was indicative of the party's deteriorating relations with the NILP.

\section{Domestic Cold War}

In the years 1949-53, events such as the formation of NATO, development of the hydrogen bomb and the outbreak of war in Korea placed new demands on CPs around the world. In Britain, the CPGB changed its line from broadly supporting the Labour Government to being highly critical. These developments naturally influenced Belfast communists. The British general election of 1950 had witnessed the elimination of CPGB representation in parliament. The Tories also re-emerged as a realistic party of government. From the CP's perspective, this

\footnotetext{
${ }^{50}$ Milotte, Communism, pp. 221-22.

51 'Facts for speakers and canvassers', 1949 (P.R.O.N.I., SMP, D/2162/A/16).

52 Ibid.
} 
pointed towards an intensification of the reactionary domestic and foreign policies of the Right-Wing Labour Government' ${ }^{53}$ Moreover, the Unionist government played 'an important part in the drive of the Tory reaction for all-out attack on the working-class standards [of living] and war'. ${ }^{54}$ In response, Belfast communists advocated industrial militancy: 'The Party will assist and endeavour to develop every strike struggle of the working class, whether on wage or bonus questions, to safeguard conditions already won, or to improve present conditions' ${ }^{55}$

This policy had both drawbacks and advantages. Across Britain communist-inspired militancy invariably led to the victimisation of activists. ${ }^{56} \mathrm{~A}$ notable example occurred in Belfast during 1949-50 when Andy Barr, a leading party trade unionist, lost his job for addressing workers during a demarcation dispute. ${ }^{57}$ After a ten-week strike, his reinstatement marked 'a salutary defeat for management and a worthy victory for the trade unions' ${ }^{58}$ On the other hand, a leading industrial cadre, Malachy Gray, received a ban from holding office in the ATGWU in 1949. He was just one victim of the worsening Cold War, a period when the British TUC called upon 'European trade unions to "counteract the activities of the Communists wherever they may be found"'. ${ }^{59}$ In 1949, against this backdrop, the CP was just one of a number of groups the NILP proscribed to insulate itself from communist and nationalist encroachment. ${ }^{60}$

\footnotetext{
53 'Communist Party: Executive Committee Letter', 7 Mar. 1950 (P.R.O.N.I., SMP, D/2162/A/18).

${ }^{54}$ Ibid.

55 Ibid.

${ }^{56}$ Richard Stevens, 'Cold War Politics: Communism and Anti-Communism in the Trade Unions', in A. Campbell, N. Fishman and J. McIlroy (eds), The Post-War Compromise: British Trade Unions and Industrial Politics 194564 (Monmouth, 2007), p. 169.

${ }^{57}$ Devine, 'Undiminished Dream: Andy Barr', p. 97.

${ }^{58}$ Ibid.

59 TUC, cited in John Callaghan, Cold War, p. 230.

60 The NILP proscribed the following in 1949; 'Commonwealth Labour Party, The Anti-Partitionist League of Ireland, The (Irish) Labour Party, The Irish Labour Association, The Communist Party of Ireland, The Labour Research Department, The British Soviet Society, West Belfast (Independent) Labour Party, University Labour Federation, World Federation of Democratic Youth'. 'Report of the Executive Committee to the $26^{\text {th }}$ annual conference NILP', 18-19 Sept. 1949 (P.R.O.N.I., BTC, D/1050/17/125).
} 
The line on 'Peace' found its way into the industrial field through the party's opposition to the Marshall Plan. Communists renounced the emphasis on increased productivity it associated with the Plan because it amounted to 'warmongering' and 'rearmament' at America's bequest. ${ }^{61}$ This placed the CP in direct opposition to the NILP, British Labour, the Irish governments, North and South, and the TUCs in Britain and Ireland. Therefore, the communist led Belfast Peace Council's collection of over ten thousand signatures represented an impressive achievement. Yet the failure to hold a Peace Conference under the auspices of the Belfast and District Trades Council during 1949-50 demonstrated how the domestic Cold War isolated Belfast's communists.

During a successful campaign to prevent the conference from occurring, a leading NILP figure stated that Belfast Trades Council was a 'Communist Stooge' with six of the eighteen strong Executive Committee being communists, and a further five fellow-travellers. ${ }^{62}$ Undoubtedly, the Trades Council often had a pro-Soviet outlook because of communist influence, notably embodied in the Secretary, Betty Sinclair, the conference's chief protagonist who had to concede:

that the path to democracy and free speech is not a very smooth one in our situation in Northern Ireland, especially in view of the fact that all the Press and most of the political Parties are screaming against Peace Conferences. They fear peace more than the devil fears holy water... ${ }^{63}$

The CP could not hope to win a propaganda war against all sides of the political spectrum. The 'Peace' issue demonstrated the party held some sway over Belfast labour organisation and politics, but it also suggests that party members lacked confidence. In 1950, two leading British Communists arrived in Belfast to act as referees in an internal dispute. They were highly critical of the 'tendency to hide the Party, and to refrain from direct Party activity by making the Trades

\footnotetext{
${ }^{61}$ Seán Murray, 'Statement on Northern Ireland', 13 Feb. 1948 (P.R.O.N.I., SMP, D/2162/A/8).

62 Betty Sinclair, to Belfast press, 26 Sept. 1950 (P.R.O.N.I., BTC, D/1050/6/C/7).

${ }^{63}$ Betty Sinclair to C.M. Grieve, 11 Sept. 1950 (P.R.O.N.I., BTC, D/1050/6/D/19).
} 
Council the channel. ${ }^{64}$ It remained the case, however, that the trade union movement remained the only viable channel to exert influence. Of course, the party's opponents recognised this.

Against the backdrop of increasing international polarization, the Unionist government unsurprisingly adopted the red smear against opponents. In 1946, the government establishment the Unionist Worker to promote the Ulster Unionist Labour Association as a constitutionally sound alternative to the NILP and the CP. During the Cold War, under the new title Unionist, it frequently viewed Catholicism, nationalism and socialism through an anticommunist lens. Reports of religious sermons stating 'The Roman Catholic Church to-day is the cuckoo's nest for Communism' accompanied 'Labour Flirts with Communism' editorials. ${ }^{65}$ Deliberately ignoring the Catholic Church's deep hostility to communism, this propaganda also played to sectarian prejudices by amplifying the tendency of some Catholic countries to produce strong communist movements. It horrified the NILP, which doggedly responded by distancing itself from the CP. In 1953, the NILP programme Where Ulster Labour Stands, made clear it had 'no relations with the Communist Party, or with its fellow-travelling subsidiary organisations'. ${ }^{66}$ The party also refused to share May Day platforms with communists, and it was keen to dispel any notion of shop-floor connivance with the CP. ${ }^{67}$ Indeed, the NILP's Secretary, Samuel Napier, claimed 'that it is members of the Labour Party who present the strongest opposition to communism in the workshop, as well as in election contests' ${ }^{68}$ This was no idle boast. The CP's electoral hopes, like those of the CPGB, were usually very badly disappointed in the face of opposition from labour candidates. The

\footnotetext{
${ }^{64}$ P. Piratin 'Report on visit to Ireland', 4 Jul. 1950 (L.H.A.S.C., CP/CENT/INT/46/04).

${ }^{65}$ Unionist, Nov. 1952, Oct. 1954.

${ }^{66}$ NILP, Where Ulster Labour Stands, (Belfast, 1953).

${ }^{67}$ 'Report of the Executive Committee to the 33rd annual conference NILP', (n.d.) c. 1955-56 (P.R.O.N.I., BTC, $\mathrm{D} / 1050 / 17 / 125)$.

${ }^{68}$ Belfast Telegraph, 13 May 1955.
} 
outstanding CP poll of the 'fifties occurred in 1953, in the Bloomfield Stormont constituency, where Andy Barr polled 1,207 votes in the unusual absence of a NILP candidate. ${ }^{69}$

Between 1955 and 1961, over one million working days in Northern Ireland were lost to strikes. ${ }^{70}$ Throughout this period, the CP's industrial cadres were to the fore as organisers and negotiators, agitating on issues such as higher pay, trade union recognition and improved working conditions. They earned the respect of their workmates on the shop floor due to their sheer commitment and were elected full-time officials, shop stewards and convenors. In 1959, eleven members of the $\mathrm{CP}$ were shop stewards in the Harland \& Wolff shipyard, whilst ten party members held that office in the Short Brothers \& Harland aircraft factory. ${ }^{71}$ Jimmy Graham 'was in turn convenor of shop stewards in Shorts, chairman of the works committee there, and full-time Northern Ireland district secretary of the Engineering Union'. ${ }^{72}$ Elected full-time Northern Ireland district secretary of the Sheetmetal Workers' Union in 1953, Andy Barr was later elevated to the leadership of the Confederation of Shipbuilding and Engineering Unions, which was key in co-ordinating industry wide industrial disputes. ${ }^{73}$

In light of this, communists were viewed by Unionists, the NILP, religious ministers and the police as the cause, mastermind or the cheerleaders of industrial strife - if not all three simultaneously. In 1959, a Royal Ulster Constabulary report suggested a cynical motive lay behind the CP's involvement in industrial disputes:

there is no doubt, that the members of the Communist Party exert a great deal of influence behind the scenes in bringing about Trade disputes in Belfast. When a strike does occur the policy would appear to be that some members of the Communist party tries to take over and dictate the terms of settlement. If they are successful the Communist Party then claims the credit. ${ }^{74}$

\footnotetext{
${ }^{69}$ Ibid., p. 74.

${ }^{70}$ Aaron Edwards, A History of the Northern Ireland Labour Party: Democratic socialism and sectarianism (Manchester, 2009), p. 74.

${ }^{71}$ Commissioner, RUC Special Crime Branch, to Inspector General, 27 Feb. 1959 (P.R.O.N.I., HA/32/1/93).

72 Milotte, Communism, pp. 222-23.

73 Ibid.

74 Ibid.
} 
During the same year, David Bleakley, a leading NILP figure, Methodist Minister, and promoter of the anti-communist Moral Rearmament movement, helped inspire the formation of a multi-denominational Churches' Industrial Council to 'consider how best to combat antiChristian and Communist influences in industry in Northern Ireland' ${ }^{75}$ In 1960, it encouraged 'a general observance of Sunday, $1^{\text {st }}$ May, as a day when the needs, aspirations and responsibilities of all engaged in Industry will be linked with the worship in the Churches' ${ }^{76}$ In addition to making May Day 'Industrial Sunday', the Council attempted to persuade Belfast Trades Council into allowing it a permanent presence at its executive meetings - an initiative successfully repulsed by Betty Sinclair. ${ }^{77}$ The leading role played by communists in Belfast's labour politics throughout the 1960s suggests anti-communist endeavours made little impact on the party's activities in that sphere.

Whilst economic struggles at the workplace were central to communist activities, the CP also attempted to broaden its appeal:

The development of the Party branches in the [residential] areas is a vital Party need, and here the following branches of Party work must get attention:

Work among such organisations as the Parents Associations on such issues as education, housing, school and hospital grievances where the Party in some areas has got considerable influence... ${ }^{78}$

Time-consuming and occasionally fruitless aspects of party work, women activists, in particular, demonstrated their bona fides through dedicated engagement in these spheres. Sinclair's position as secretary of the Belfast Trades Council, helped to facilitate this work. Prior to Sinclair occupying that position, however, Sadie Menzies stood as a CP candidate in

\footnotetext{
${ }^{75}$ Northern Whig, 5 Oct. 1959. Supported by the Church of Ireland, Presbyterian, Roman Catholic and Methodist churches, the council represented a manifestation of the contemporary trend of ecumenicism in Northern Ireland. 76 J. Gordon Wilson, Hon. Secretary, Churches' Industrial Council, to Betty Sinclair, Mar. 1960. (P.R.O.N.I., BTC, D/1050/6/C/7).

77 Betty Sinclair to J. Gordon Wilson, 10 Jul. 1960 (P.R.O.N.I., BTC, D/1050/6/C/7). Representatives of the Church Industrial Council sat in on two meetings of Trades Council's executive; evidently, this development was conceived as a stepping-stone to the establishment of a permanent presence.

78 'Communist Party Conference,' 4-5 Feb. 1950 (P.R.O.N.I., SMP, D/2162/G/13).
} 
the Belfast municipal elections of September 1946, because 'she has played a big part in the campaign for houses, new schools, playgrounds for children, free school books and meals' ${ }^{79}$ Menzies also led a prolonged CP campaign on housing, particularly on behalf of squatters who had moved into huts on army property at the end of the war. The limited dividend, in terms of lasting popular support, from such activity led some male, industrial-minded, members of the party to question its utility. Certainly, this was the cause of heated exchange at the party's 1957 congress. Menzies accused Seán Murray of distinguishing 'social work and political work', and suggested that the party's 'extremely active' female members were not getting enough support in building up the National Assembly of Women 'to fight for peace and better living standards' ${ }^{80}$

By the mid-1950s, a new generation of Communists, some the children of $\mathrm{CP}$ members, graduated from the party's youth organisation, the Socialist Youth League. ${ }^{81}$ Younger communists participated in all party activities but they focused on youth issues and international concerns. The paucity of swimming pools and playing fields in Belfast, especially when compared with British cities, became favoured campaign issues along with emigration, unemployment, and condemnation of imperialism and the regime in South Africa. ${ }^{82}$ The YWL found attracting recruits as difficult as the CP, having a 'handful' of members in $1957 .{ }^{83}$ Nevertheless, it provided a crucial training ground for future CP cadres. Following the death of the Seán Murray in 1961, Jimmy Stewart, who had been secretary of the SYL in the mid1950s, finished drafting 'The Irish way to socialism', the programme, which Murray had been working on from 1957, before taking up a series of leadership roles in the party. ${ }^{84}$ If the big

\footnotetext{
${ }^{79}$ Unity, 14 Sept. 1946.

80 'Minutes of CP congress', 13 Apr. 1957 (P.R.O.N.I., SMP, D/2162/ G/47).

${ }^{81}$ Interview with Jimmy Stewart of Belfast (7 May. 2008).

82 Ibid.

83 'Minutes of CP Congress', 13 Apr. 1957 (P.R.O.N.I., SMP, D/2162/ G/47).

${ }^{84}$ Interview with Jimmy Stewart of Belfast, (7 May 2008).
} 
picture denotes a party with no presence in most of the north and across many industries, the detail on the ground reveals much activity. Communists were always actively involved in grass-roots issues and their incessant demands for, amongst other things, higher wages, reduced rents and lower prices rooted them in the community.

Nevertheless intelligence gathered by the United States Consulate in Belfast from 'informed (NILP) sources' in the late 1950s suggests the CP was 'a "milk and water" organization incapable of any serious subversive activity' partially due to its 'poor financial standing'. ${ }^{85}$ This was an accurate assessment. In 1959, after two years of struggling against prohibitive costs, the $\mathrm{CP}$ had to forgo its party premises and the 'International bookshop' in central Belfast. One unforeseen consequence was the difficulty in trying to locate new more cost-effective party premises, a process that took four months. Sean Murray 'thought we would never get another place; everywhere the frightening power of "C.P." was far in excess of that attributed to his Satanic Majesty' ${ }^{86}$

A lack of funds may explain why the party did not participate in the 1958 Stormont election even if Milotte suggests the abandonment of electioneering signified a failure to present a serious ideological alternative to the 'firmly pro-partitionist NILP', which was 'campaigning vigorously for the defence of the border and the suppression of republicanism,' against the backdrop of the Irish republican Army's 'Border campaign.${ }^{87}$ Communists certainly held the NILP in higher regard than the Unionist Party, but the NILP's 1953 programme, Where Ulster Labour Stands, had demonstrated that it was not only in industrial and electoral matters that the NILP desired to separate itself from the CP. That the NILP was sound on the border was repeatedly emphasised, whereas:

\footnotetext{
85 Anderson to State Department, 17 Jan. 1955 College Park, Maryland, National Archives and Record Administration (741A.00/1-1755).

${ }^{86}$ Seán Murray to Peter [Kerrigan?] 9 Jul. 1959 (P.R.O.N.I., SMP, D/2162/G/80).

${ }^{87}$ Milotte, Communism, p. 230.
} 
The Communists in Ulster believe in the use of force; they believe in the ending of the border; they believe in revolution and not reform. Unionist speakers sometimes try to persuade the electors that Socialism and Communism are the same. Nothing could be farther from the truth. ${ }^{88}$

The CP's furious response is informative. A 'Political Letter' from the Secretariat to the rank and file described the programme as 'the biggest step taken by the Party to appease the Unionist Imperialists'. It went on to attack the NILP from perspectives usually associated with northern nationalism:

[The NILP] takes on the defence of the present situation in N. Ireland, in opposition to the whole of the Irish Labour Movement, North and South, and places itself in violent opposition to big sections of opinion within the British Labour Movement... But the NILP officials go in practice much further than support for the Unionist Party on the Border issue. They take issue with all who criticise the internal situation within the Six Counties on such questions as democratic rights. ${ }^{89}$

If the NILP ideologically differentiated itself from the CP, the reverse was true. However, as the US consulate's intelligence report suggests, the national question remained problematic: 'Although admittedly the Communist Party directs its appeals to the malcontents of all shades and descriptions, it is difficult for them to cut across both sides of the Partition fence' ${ }^{90}$

\section{The CP and the National Question}

If Irish neutrality during the war caused the liquidation of communism in Éire, an obvious question is why did the erstwhile Dublin communists not link up with their Belfast counterparts to re-establish an all-Ireland party after it? Milotte argues Éire's wartime isolation meant that 'Unionism was deemed more progressive than republican separatism... the scattered remnants of the old CPI in Dublin, unwilling to advocate such policies in public remained dormant', whilst the $\mathrm{CP}$ 'operated as though it were simply part of the British left and the Six Counties

\footnotetext{
${ }^{88}$ NILP, Where Ulster Labour Stands, (Belfast, 1953).

89 'Political letter no. 46,' 5 Oct. 1953 (P.R.O.N.I., SMP, D/2162/A/37).

90 Anderson to State Department, 17 Jan. 1955 College Park, Maryland, National Archives and Record

Administration (741A.00/1-1755).
} 
an integral part of Britain' ${ }^{91}$ Intelligence documents suggest that 'up to April 47, however, the members in the 26 counties remained under the control of the National Committee which functioned from Belfast'. ${ }^{92}$ Therefore, technically the war had not left 'communism partitioned' in the sense conveyed by Milotte. Indeed, although partition profoundly affected Irish communism it does not provide an adequate explanation the for the Irish Workers' League's (IWL) foundation as a southern Irish communist party, in all but name, in 1948. Milotte's account devotes insufficient attention the post-war interlude 1945-48.

Southern communist activity in the immediate post war period concentrated on creating a base amongst sympathetic students, disaffected youth, republicans, the Labour left and 'progressive' elements within the middle and working classes. The difficulty of this task held back those trying to implement the goal of a re-invigorated communist movement. Until, that is, the forlorn nature of underground work within Labour and other bodies emerged into clearer relief, and when the needs of the international communist movement demanded a response. Moreover, the decision to remain clandestine, largely due to the threat of anti-communism, blocked any remaining hopes for an open link up with the CP in the North. ${ }^{93}$ A 1948 Irish intelligence summary of Irish communist activities, notably connecting them with contemporaneous international events, provides a useful summary of the IWL's creative nomenclature:

all open attempts at Communist propaganda have been the subject of careful watch and opposition by the religious and other bodies. A project of the Communist Group in Dublin to launch an Irish Socialist Party has been under consideration for a considerable period. It was considered that such a Party, while dominated by communists, would attract people who would not join a Communist Party as such. It was also considered that, because such a party was not called Communist, it might avoid some of the opposition which a purely communist Party would be certain to meet...The international and local political situation was discussed at this meeting and the formation of a militant communist party under another name was agreed upon... This anti-war campaign is, of course only a feature of the general antiwar and pro-Russian campaign which communists are conducting all over Europe at present. It is not

\footnotetext{
${ }^{91}$ Mike Milotte, Communism, p. 217.

92 'Communism in Ireland', Department of Justice report, 31 Dec.1947, Dublin, University College Dublin Archives (U.C.D.A.) MacEntee Papers (P67/548).

93 Patrick Smylie, Irish communism 1945-70: Cold War, partition and convergence' (PhD, Queen's University

Belfast, 2010), pp. 60-73.
} 
suggested that this proposed party may succeed even in a small way but this report is submitted with a view to indicating the lines on which those people are thinking and also as indicating their common action with other European communist parties. ${ }^{94}$

This did not fool Ireland's vigilant Cold War warriors, who quickly recognised the IWL as communist and treated it accordingly. Nevertheless, it is clear that fears of clerical reaction and possible government repression in Dublin, as much as the alleged British orientation of Belfast's communists prevented the re-establishment of an all-Ireland communist party.

By placing the national question backstage, however, the CP (and the NILP) became open to attack by leftist rivals with avowedly nationalist or republican perspectives. The Northern Star, journal of the Belfast based Socialist Republican Party, argued:

... in spite of claiming to hold the Socialist ideal, the Labour and Communist leaders have never got over the influence of their early environment. Reared for the most part, in homes where the connection with England was regarded as right and natural, they find it difficult to break with the past and recognise the union [between Britain and Ireland] as the root of all our evil. ${ }^{95}$

To varying degrees, this sentiment echoes in the historiography. Byers argues the CP opposed Ulster Unionism but not the 'integrative effects of the British social democratic and welfare state'. And, that Seán Murray's 'loyalty' to the welfare state represented a 'profound irony' in the thinking of the ideologically committed republican/communist leader. ${ }^{96}$ Arguably, this assumes that Murray, and similarly minded communists and republicans, were absolutist in their Anglophobia. They were not and communists could plausibly credit the successes of the welfare state and simultaneously believe it could act as a model for progress in Ireland. Of course, as a communist, Murray's political ambitions extended beyond what British 'integrative' social democracy delivered.

\footnotetext{
${ }^{94}$ Intelligence note on 'Communist Activities', 11 Oct. 48, Dublin, National Archives of Ireland (DFA A 55.1).

${ }^{95}$ Northern Star, Feb. 1946.

${ }^{96}$ Byers, Murray, pp. 149-150.
} 
Milotte argues the CP's 'completely British orientation' isolated it from the 'Catholic section of the working class' ${ }^{97}$ Undoubtedly, many Catholics had difficulty relating to a party whose membership and broader support largely originated from protestant East Belfast. ${ }^{98}$ Equally, many CP members located in Belfast would naturally have identified with the British labour movement. ${ }^{99}$ The explanatory historical context is Protestant domination of the skilled trades in Belfast, where the union tradition in craftwork, alongside sectarian discrimination, ensured Catholics were mostly restricted to unskilled employment. ${ }^{100}$ The Catholic Church's opposition to communism also helped to marginalise the CP. Sean Morrissey has recalled how, as a practicing Catholic from West Belfast, he consulted a priest after joining the party in the mid-1950s, and that 'he suffered for it'. The priest made it clear Catholicism and communism were incompatible and Morrissey believes that if not for his work in Tenant Associations, he would have been 'chased or isolated'. ${ }^{101}$

Citing a $1951 \mathrm{CP}$ document, which stated the ITUC should headquarter itself in Belfast to cater solely for Northern Irish workers organised in British-based trade unions (with the rival Irish Congress of Trade Unions taking responsibility for Irish workers and unions) Milotte correctly suggests this delineated 'the permanent division of the trade union movement along the lines of the border' ${ }^{102}$ Yet there is no evidence to suggest this was the established line. Milotte concedes that the idea was 'mooted', and suggests that the CP retreated on the Northern Ireland TUC stance under pressure from the IWL. This in itself indicates all-Ireland

\footnotetext{
${ }^{97}$ Milotte, Communism, p. 221.

${ }^{98}$ Although a number communists from protestant backgrounds married Catholics. These included Hugh Moore, the party's General Secretary in the 1960s and Eddie Spence, whose brother Gusty, a founding member of the loyalist paramilitary Ulster Volunteer Force, beat him up on his wedding day. Interview with Barry Bruton of Belfast (14 Nov. 2009).

${ }^{99}$ See Emmet O' Connor, 'Sheep in Wolves' Clothing: Labour and Politics in Belfast 1881-1914' in F. Devine, F. Lane, and N. Puirséil (eds), Essays in Irish Labour History: A Festschrift for Elizabeth and John W. Boyle (Dublin, 2008), pp 65-83.

100 Terry Cradden, Trade Unionism, p. 16.

${ }^{101}$ Interview with Sean Morrissey of Antrim, County Antrim (12 May 2010).

102 Milotte, Communism, p. 223.
} 
coordination between the two parties, but Milotte suggests that in return the $\mathrm{CP}$ demanded the IWL play down the national question. Significantly, he fails to provide any evidence for the latter argument.

In fact, the CP increasingly adopted all-Ireland perspectives throughout the 1950s. In October 1952, Stalin elucidated 'the united front of all patriots' and this rhetoric quickly found its way into CP literature. The Political Letter of November 1952, for instance, agreed with Stalin that 'the Communist and Democratic Parties must pick up the banner of the National Independence of their countries' before going on to suggest:

We fight for... the development of the closest bonds of solidarity with the W. Class of the two areas as the steps to the integration of the economy of the whole country and the achievement of an independent, united Ireland marching on the road to Socialism. ${ }^{103}$

The CPGB was also keen to promote an all-Ireland communist ethos as it could potentially make communism more attractive to the rapidly growing Irish community in Britain. To further this goal the British party encouraged the creation of a Joint Council of the Executive Committees of the CP and the IWL in November 1952. Championed in Ireland by Murray and Sean Nolan of the IWL, this body intended to:

Strengthen the work of the Communist Party and the Irish Workers League, politically and organisationally, in the common struggle for the victory of world peace and the more effective implementation of the policies of the Party and the League on national and domestic issues

Strengthen both organisations in Dublin and Belfast, and in the provincial towns of both areas

Strengthen the position of the Communist Party in relation to Irish national politics and the position of the IWL within the Labour-Trade Union Movement.

Develop a common policy and plan of activity in the fight for Trade Union unity

Develop close co-operation in pushing the respective policies of the two organisations for the struggle against American-British Imperialism, defence of the independence of the Republic and discussion on the lines of approach of the goal of the unity and independence of the country. ${ }^{104}$

The Joint Council did not live up to expectations in London, where the CPGB lost patience with Irish communists who failed to produce a cohesive programme that could rouse a broader

103 'Political letter No. 9, 10 Nov. 1952, (P.R.O.N.I, SMP, D/2162/A/29).

104 'Joint Council', Nov. 1952 (P.R.O.N.I., SMP, D/2162/G/24). 
coalition of 'progressive' forces. ${ }^{105}$ However, it did foster closer ties between the two parties. For instance, the Irish Workers' Voice, organ of the IWL, carried a 'Northern Letter' from its first issue in 1949, and northern content was boosted in 1952 when CP members under the heading 'Northern Edition' produced one page of the journal to be sold in Dublin and Belfast. ${ }^{106}$

The paper did not survive the tumultuous events of 1956. Communists in both Irish jurisdictions responded to Khrushchev's speech at the $20^{\text {th }}$ congress of the Soviet Union's Communist Party, which revealed for the first times the errors and criminal activities of the USSR under Stalin, with stunned disbelief. ${ }^{107}$ Nevertheless, they quickly adopted the international line, conceding that 'the stifling of democracy of the Soviet Party and State' had occurred whilst blaming 'the evils attendant on the Stalin Cult' ${ }^{108}$ The revolution in Hungary had a broader impact especially in Dublin, where the IWL came under immense pressure from reinvigorated anti-communist agitation. This included a violent attack on the party's premises by a large crowd. This level of opposition did not manifest in Belfast, but there were instances of Catholic anti-communist activism in the city during the late 1950s. ${ }^{109}$

Widespread anti-communist sentiment in southern Ireland did not affect the CP's resolve to continue working closely with the IWL and nor did the outbreak of the IRA's border campaign, in December 1956, undermine the party's rhetorical commitment to end partition. At the April 1957 Party Congress, Young Workers' League members spoke in favour of Irish unity, with Seán Murray adding the important caveat that 'mass action not military action' was

\footnotetext{
105 Patrick Smylie, 'The CPGB, the Connolly Association and Irish communism 1945-1962' Labor History, Vol. 59, no. 2 (2018).

106 'Political Letter No. 32', 27 May 1953 (P.R.O.N.I., SMP, D/2162/A/36).

${ }^{107}$ Interview with Jimmy Stewart of Belfast, County Antrim (7 May 2008); Interview with Sam Nolan of Dublin (16 Mar. 2010).

108 'The $20^{\text {th }}$ Congress of the Russian Communist Party Statement by the Executive Committee of the Communist Party', 1956 (P.R.O.N.I., SMP, D/2162/G/42).

${ }^{109}$ For instance, protesters belonging to Fírinne (Maria Duce), a Dublin based Roman Catholic lay group, picketed activities related to a Soviet cultural delegation to Belfast in November 1956. 'Membership of Communist Party; reports on British-Soviet Friendship Society’, 29 Oct. 1956 (P.R.O.N.I., HA/32/1/938).
} 
required. ${ }^{110}$ The Congress occurred only a month after Brookeborough (the ennobled Brooke) had directly linked the party to the IRA's Border campaign:

It is interesting that for a long time I have believed that there is a very close link between these outrages and the Communist Party - it is such an obvious chance for the Communist Party to raise trouble -and there are indications that my guess was right. ${ }^{111}$

This attempt to associate the IRA with communism (and vice versa) had little basis in reality. A week earlier, a Sinn Féin spokesperson in Dublin claimed that 'anyone who suggested Communist control or cooperation could have that suggestion thrown in their teeth'. ${ }^{12}$ In a sense, Brookeborough's conjecture represented a recognition of $\mathrm{CP}$ influence in industrial relations, and an adoption of a green smear to undermine it. It also reflects, that in sharp contrast to the NILP', communists were 'articulating demands for democratic reform of the northern state,' notably in relation to local government elections, the use of the draconian Special Powers Act, as well as government recognition of the NIC. ${ }^{113}$

The CP's 1962 programme, Ireland's Path to Socialism confirmed, along with its IWL counterpart Ireland Her Own, the absence of a revolutionary Marxist-Leninist tendency during the post-war era. Rather than the vanguard-led overthrow of parliaments by risen workers, either with or without IRA support, the preferred modus operandi was to work within the existing structures of the northern and southern states for 'the advance to power of a popular people's movement... a return to Parliament of a majority of representatives based on the popular will'. ${ }^{114}$ Of course, this reflected prevailing realities on the ground, as Betty Sinclair recalled: 'the war had taught us a lot; we realised we had two different governments to contend with and two different sets of legislation'. ${ }^{115}$ It also clearly recognised what Murray described

\footnotetext{
${ }^{110}$ NILP, Where Ulster Labour Stands, (Belfast, 1953).

${ }^{111}$ Northern Ireland House of Commons, 5 Feb, 1957, Vol. 41, pp 30-31.

112 Belfast Telegraph, 26 Jan. 1957.

113 Byers, p. 173.

${ }^{114}$ Communist Party Northern Ireland, Ireland's Path to Socialism, (Belfast, 1962).

115 Sinclair cited in Morrissey, 'Betty Sinclair', p. 127.
} 
as 'cultural differences' in Ireland which it would 'be playing the ostrich to deny'. ${ }^{116}$ Murray was chiefly referring to the unwillingness of Protestant workers to abandon their Unionist perspective, despite the party's consistent propaganda on such ills as the Marshall Plan: 'The Americans have ordered Britain to cut down shipbuilding so that the surplus ships in USA can be lent or sold to us. Ship-building is cut. Thousands of shipyard workers are menaced from now on with the sack'. ${ }^{117}$

This analysis had potential in a period when thousands of jobs in the heavy industries were under threat. However, the party's undoubted achievements in the industrial sphere did not stem from anti-imperialist lines emanating from Moscow, or even the long-term objective of a united Ireland under socialism. The undoubted primacy of practical work in industry, the proverbial coalface, should be viewed as the pragmatic foundation of the party's continued existence in bleak Cold War conditions. Milotte's argument that this 'economistic' approach represented a deliberate distraction from the overriding national issue fails to convince. ${ }^{118}$ Such pragmatism logically emerged from shared real-world experiences of trade union activists of the Communist Party, the NILP, and of no party.

\section{Conclusion}

If during the post-war era, events pushed the NILP towards a pro-Union stance, it is arguable that they guided the $\mathrm{CP}$ towards an increasingly anti-partitionist position. In the immediate post-war period, support for the status quo appeared to constitute a promising avenue for communist progress. Membership was robust and the possibility of a rapprochement with the NILP was apparent in tentative electoral co-operation and a mooted merger between the parties.

\footnotetext{
116 Seán Murray, untitled document (n.d.) c. 1948 (P.R.O.N.I., SMP, D/2162/J/45A).

117 Seán Murray, 'Statement on Northern Ireland', 13 Feb. 1948 (P.R.O.N.I., SMP, D/2162/A/8).

118 Milotte, Communism, p. 229.
} 
Added to this, the majority of CP members and supporters came from the Protestant workingclass. For them, the welfare state under construction in Britain was far in advance of the social system in place in southern Ireland. However, several developments precipitated a reassessment of the CP's position, chief among them the onset of a domestic Cold War. This development should be viewed in relation to the position of the Unionist government which, alarmed by the post-war labourist upsurge, repeatedly propagated links between the $\mathrm{CP}$ and NILP as a stick to beat the latter, and opportunistically utilised southern political machinations effectively to hold a referendum on the national question with the election in 1949. Having adopted a partitionist stance on the national question shortly before 'Brooke's plebiscite', the continuing impact of the international and domestic Cold War further estranged the NILP from the CP. Therefore, with the NILP adopting a definite partitionist and, more significantly, anticommunist stance, the CP's early optimism was stifled by the onset of the Cold War and heightened tensions surrounding the national question.

This coincided with a distinct retraction in party membership and a decline in party organisation, with the exception of involvement in industrial relations where the CP's militancy and centralised organisation ensured its survival even in a domestic Cold War context. Therefore, the party was in no position to challenge the Unionist party or the NILP on a shared platform. The fact this was never considered suggests the objective of a united socialist republic was always the overriding long-term objective. Moreover, the impact of the Cold War led to developments in southern politics, which would encourage closer co-operation between the CP and the IWL. On first inspection, the External Relations Act should have hindered co-operation between northern and southern communists as it heightened potentially divisive national issues. However, the communist perspective on the Cold War superseded such concerns. Supporting 'Peace' and challenging perceived American and British 'imperialist' policy aims (epitomised by the Marshall Plan) encouraged the development of common ground, and was fostered by 
the CPGB. Unsurprisingly, the ideological battles of the domestic Cold War primarily related to the CP's exalted position in the trade unions. In this arena however, $\mathrm{CP}$ cadres predominantly occupied themselves with the day-to-day economic issues, which affected the predominantly Protestant skilled workforce in Belfast's heavy industries. This meant the party remained largely isolated from Catholic workers. However, whilst the CP's focus on industrial militancy would continue into the 1960s, Irish communists would also increasingly target the Unionist government's record on 'democratic rights' as the focal point of a northern platform. 